\title{
Sağlık Çalışanlarında Duygusal Emek ile ilgili Yapılan Çalışmalara Yönelik Bir İnceleme
}

An Examination For Studies Related to Emotional Labour on Health Personnel

\author{
Arş. Gör. Birol Yetim ${ }^{1}$ - Doç. Dr. Gülsün Erigüç²
}

Başvuru Tarihi: 05.03.2018

Kabul Tarihi: 09.04.2019

\section{Öz}

Bu çalışmanın amacı, duygusal emek kavramı ile ilgili Türkiye'de ve sağlık alanında yapılmış olan araştırmaları incelemek; araştırmaların yapıldiğı hedef grupları ortaya koymak; kullanılan ölçekleri tespit etmek ve bundan sonraki çalışmalarda yol gösterici olabilmektir. Duygusal emek ile ilgili yapılmış çalışmalara ulaşabilmek için YÖK Tez Arama Merkezi, Ulakbim, Google Akademik, Science Direct, Scopus ve EBSCOhost elektronik veri tabanları taranmıştır. Ulaşılan araştırmalar bu çalışma için belirlenen kriterlere göre elenmiş ve 19 araştırma çalışmaya dâhil edilmiştir. Elde edilen tanımlayıcı bulgular, çalışmaların yaklaşık \% 73'ünün araştırma makalesi; \% 21,6'sının yüksek lisans tezi ve \% 5,25'inin ise doktora tezi olduğunu göstermektedir. Çalışmalarda duygusal emek kavramıyla birlikte en çok incelenen kavramlar ise sırasıyla, tükenmişlik, işten ayrılma niyeti ve çalışan davranışlarıdır.

Anahtar Kelimeler: Duygusal Emek, Sağlık Çalışanları, Literatür İncelemesi

\begin{abstract}
The aim of this study is to examine related studies with emotional labour carried out in Turkey and in health field; to identify target groups of the studies, to determine scales that have been used and to be a guidance for further studies. Electronic databases of YÖK Thesis Search Center, Ulakbim, Google Academic, Science Direct, Scopus, and EBSCOhost were scanned in order to reach to studies related to emotional labour. Studies were eliminated by considering elimination criteria for this review and 19 studies were included in this study. Descriptive study findings show that $73 \%$ of the studies were research articles, $21.6 \%$ of them are master's thesis and $5.25 \%$ of them are doctorate thesis. The most examined concepts in the studies, together with the concept of emotional labour, are burnout, turnover intention and employee behaviours, respectively.
\end{abstract}

Keywords: Emotional Labour, Health Personnel, Literature Review

\footnotetext{
${ }^{1}$ Hacettepe Üniversitesi İİB, birolyetim@hacettepe.edu.tr, ORCID: 0000-0002-1294-1874

${ }^{2}$ Hacettepe Üniversitesi İIBB, geriguc@hacettepe.edu.tr, ORCID: 0000-0001-5186-9345
} 


\section{Giriş}

Son yıllarda hizmet sektörünün hızla büyümesi ile birlikte, "insanın bilinçli olarak giriştiği çalışma sürecinin, kendi iç dünyasında uyandırdı̆̆ı izlenim” olarak tanımlanan duygusal emek kavramı, birçok mesleğin ve hizmet alanının vazgeçilmez bir bileşeni olmuştur (Basım ve Beğenirbaş, 2012, s.2). Zira teknolojik gelişmeler ve yoğun çalışma temposu nedeniyle, çalışanlar çoğu zaman stresli, yorgun ve mutsuzdur. Bunlara rağmen örgüt yöneticileri, çalışanlarından işlerini en iyi şekilde yapmalarını beklemektedirler. Bunun bir sonucu olarak da, çalışanlardan hissettikleri olumsuz duyguları karşı tarafa yansıtmamaları hatta işlerinin gerektirdiği duyguları sergilemeleri istenmektedir (Kafadar ve Kaygın, 2017, s.78). Bu istek, çalışanların müşteriler ile daha fazla temas kurmalarına ve beraberinde bir takım özelliklerini de ön plana çıkarmalarına neden olmaktadır. Günümüzde sadece işin doğru yapılması çoğu zaman yeterli görülmemekte aynı zamanda çalışanlardan doğru davranışlar sergileyerek onlardan hizmet alan kişilerin taleplerini yerine getirecek duygular ile işlerini yapmaları ve böylelikle müşteri memnuniyetini olabildiğince iyileştirmeleri istenmektedir (Çelik ve Turunç, 2011, s. 228). İşte tam burada ifade edilen "duygular ile işlerini yapmak" yapilacak işten kaynaklanan ya da işe karşı hissedilen bir duygu ile hareket etmek değildir. Aksine işi belirlenmiş bir duygu ifadesi takınarak yapmak ve hizmet alan kişilerde o hissi uyandırmaktır. Bu çabaya ise "duygusal emek" denilmektedir (Seçer, 2005, s. 814).

İşgören ve müşteri ilişkilerinde sadece doğru davranış sergilemenin yeterli görülmediği, işgörenlerden hizmet alanlara karşı duygusal davranışlar göstermeleri beklendiği günümüzde, duygusal emek kavramı, özellikle hizmet sektörü için oldukça önemlidir. Ancak bu durum hizmet sektöründe bir takım olumlu ve olumsuz durumları beraberinde getirebilir. Verimlilik artışı, sunulan hizmetin kalitesinin yükselmesi ve müşteri memnuniyetin artması, duygusal emek sonucu ortaya çıkan olumlu durumlar arasında sayılabilir. Ancak işgörenin psikolojik ve fizyolojik rahatsızlıklar yaşaması, tükenmişlik ve yabancılaşma gibi durumlar meydana gelebilmektedir (Oral ve Köse, 2011, s. 465).

\section{Duygusal Emek}

Literatür incelendiğinde duygusal emek kavramını ilk olarak 1979 yılında Arlie Russell Horchschild'in “The Managed Heart” adlı kitabında ele aldığı görülmektedir (Hochschild, 1979). Takip eden yıllarda duygusal emek konulu yeni çalışmalar yapılmış ve duygusal emek kavramı farklı bakış açılarıyla ele alınmıştır. Üzerinde çok sayıda araştırma yapılmış olsa da, duygusal emek kavramı sıklıkla dört yaklaşım ile incelenmektedir (Tunç, 2012, s. 43). Bunlar araştırmaların yapıldıkları yıllara göre sırasıyla; Hochschild yaklaşımı (1979), Ashforth ve Humphrey yaklaşımı (1993), Morris ve Feldman yaklaşımı (1996), ve Grandey yaklaşımıdır (2000).

\section{Hochschild'in Duygusal Emek Yaklaşımı}

Bu yaklaşımlardan Hochschild'in (1983, s.7) yaptığı tanıma göre duygusal emek, çalışanların duygularını yöneterek, gözlemlenebilir yüz ve beden hareketeriyle karşı tarafa yansıtması demektir. Ayrıca Hochschild'e göre duygusal emek bir ücret karşılığında yapılmaktadır ve bu nedenle değişim değeri vardır. Öte yandan duygusal emek kavramını derinlemesine ve yüzeysel 
davranışlar olmak üzere iki temel mekanizma olarak ele almaktadır. Hochschild derinlemesine davranışı, işgörenin gösterdiği bir çabanın ürünü olmayıp duyguların doğal bir şekilde ifade edilmesi olarak tanımlarken yüzeysel davranışı, işgörenin davranışlarını değiştirerek aslında hissettmediği bir duyguyu hissediyormuş gibi davranması olarak ifade etmektedir.

Hochschild, meslek gruplarını duygusal emek gerektiren ve gerektirmeyen meslekler olarakta ikiye ayırmıştır. Hochschild'in yaptı̆̆ı sınıflandırmaya göre duygusal emek gerektiren meslek gruplarının başında; avukatlar, doktorlar ve öğretmenler, yöneticiler, satış görevlileri, memurlar, çocuk bakıcıları ve garsonlar gelmektedir. Ayrıca Hochschild çalışma sonucunda bu meslek gruplarında çalışan kadınların erkeklere göre duygusal emek davranışı sergileme konusunda daha başarılı olduklarını bulmuştur (Hochschild, 1983, ss. 244-251).

\section{Ashforth ve Humphrey'in Duygusal Emek Yaklaşımı}

Duygusal emek kavramını, hizmet süreci boyunca örgütün arzulamış olduğu davranışların örgütten hizmet alanlara yansitılması olarak tanımlayan Ashforth ve Humphrey, Hochschild'in iki boyutlu duygusal emek kavramına ek olarak samimi davranış kavramını da kullanmışlardır ve duygusal emeği, derinlemesine davranış, yüzeysel davranış ve samimi davranış olmak üzere 3 temel mekanizmada ele alıp incelemişlerdir (Ashforth ve Humphrey, 1993, s. 88). Yazarlar, derinlemesine davranış ve yüzeysel davranış gösteren işgörenlerin bu davranışlar için bir çaba içinde oldukları için belirli bir zaman sonra bu davranışların artık kendiliğinden gerçekleşebileceğini ileri sürmektedir. Ancak samimi davranışı, işgörenlerin gerçekten hissettiklerini yansıtması olarak tanımlamaktadırlar. Yani samimi davranış türünde işgörenlerin işin ya da örgütün isteklerine göre rol yapmasına gerek yoktur.

Bu yaklaşımı Hochschild'in (1983) duygusal emek yaklaşımından ayıran en önemli özellikse, yaklaşımın çalışan davranışlarının nedenlerinden ziyade doğrudan davranışın kendisine odaklanmasıdır. Çünkü Ashforth ve Humphrey’e göre hizmet sunumunda önemli olan şey dışarıdan gözlemlenebilen davranışlardır (Pugh, 2001, s. 1024).

\section{Morris ve Feldman'ın Duygusal Emek Yaklaşımı}

Morris ve Feldman (1996, s. 987) ise, duygusal emeği kişiler arası ilişkilerde örgütün istediği duyguları sergileyebilmek için sarf edilen çaba, planlama ve kontrol olarak tanımlamaktadır. Diğer yaklaşımlardan farklı olarak bu yaklaşıma göre, işgörenin o anda hissettikleri duygu ile sergilemesi gereken davranış bir uyum içinde olabilir ancak örgütün istediği davranışın tam anlamıyla sergilenebilmesi için işgörenin bir çaba sarf etmesi gerekmektedir. 


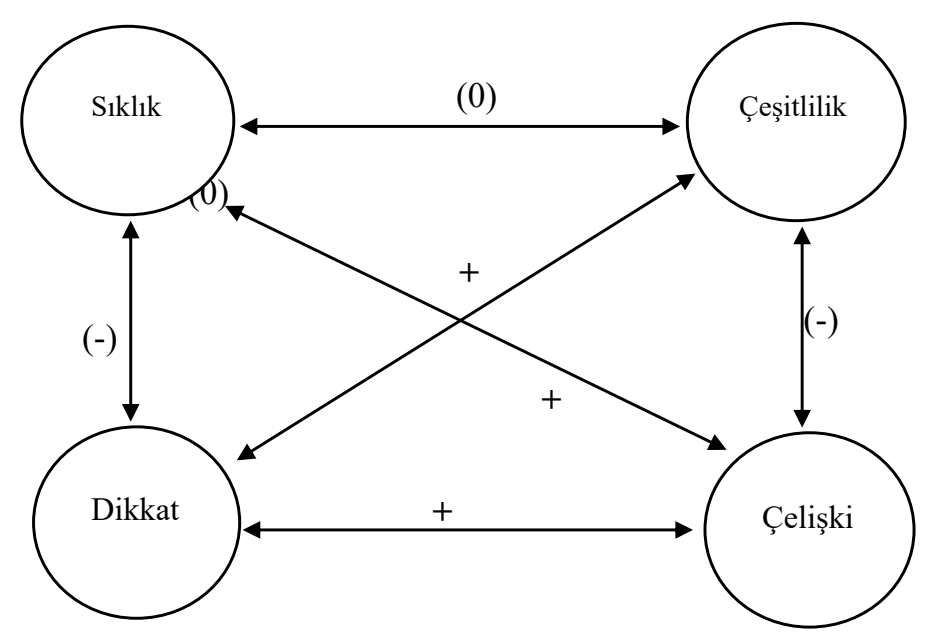

Şekil 1. Duygusal Emek ve Boyutları Arasındaki iliş̧ki

Kaynak: Morris ve Feldman (1996, s.993)

Bu yaklaşımda duygusal emek, birbirini etkileyen 4 boyutta ele alınmıştır (bknz. Şekil 1). Bunlar (Morris ve Feldman, 1996, ss. 989-994);

Uygun duygusal davranışın gösterilmesindeki sıklık; duygusal emek davranışın işgörenlerin müşteri ile ne kadar sık iletişime geçtiği ile yakından ilgilidir. Bu sıklık arttıkça işgörenler örgüt kurallarını daha çok sergilemek zorunda kalacak ve bu durum işgörenler için daha çok duygusal emek ihtiyacını ortaya çıkaracaktır. Ayrıca davranış sıklığı ile duygusal çelişki arasındada pozitif bir ilişki vardır. Yani işgörenlerin müşteriler ile iletişimi uzadıkça ve davranış sıklığı arttıkça daha fazla duygusal çelişki yaşayacaktır.

Gerekli davranış kurallarına gösterilen dikkat; işgörenler örgütün belirlediği kurallara daha çok dikkat ettikçe hem psikolojik olarak hem de fiziksel olarak daha çok çaba harcamak zorunda kalacaklar.

Duyguların çeşitlilik ise bir diğer boyuttur. İşgörenler müşterilerine ne kadar çok duygu yaşatmak zorunda kalırsa o kadar çok duygusal emeğe ihtiyaç duyacaktır. Bu durum ise davranışların çeşitlenmesine neden olmak ile beraber işgörenlerin davranışlarını daha çok kontrol altında tutmaya zorlanmasina neden olacaktır.

Duygusal çelişki ise dördüncü boyut olarak karşımıza çıkmaktadır. Duygusal çelişki ise, işgörenden sergilemesi istenilen davranış ile işgörenin sergilediği davranış arasındaki fark olarak tanımlanabilir. 


\section{Grandey'in Duygusal Emek Yaklaşımı}

Bir diğer yaklaşım ise; Grandey’in (2000) yaklaşımıdır. Yazara göre duygusal emek, işgörenlerin örgütün talep ettiği şekilde duygularını ayarlama sürecinde harcadıkları çaba olarak tanımlanmıştır (Grandey, 2000). Ayrıca yazar, çalışanların duygusal emek davranışları üzerinde etkili olan dört temel faktör üzerinde durmaktadır. Bu faktörler; iletişimin türü ve içeriği, iletişimin geçiciliği, etkileşim sürecindeki otonomi ve etkileşimin karmaşıklık düzeyidir (Grandey ve Diamond, 2010, s. 339).

Yazar, konu hakkında yapılmış önceki çalışmaları bütünleştirerek yeni bir duygusal emek modeli geliştirmiştir. $\mathrm{Bu}$ model öncelikle, eski çalışmaların bir birleşimi niteliğindedir. $\mathrm{Bu}$ çalışmanın önemi ise, yazar işgörenlerin yeni bir durum ile karşılaştığında duygularını kontrol etmesi olarak tanımladığı duygu düzenlemesi kavramını yeni modele eklemesidir (KöseOral ve Türesin, 2011, s. 170).

\section{Duygusal Emek Davranışları}

Önceleri derinlemesine ve yüzeysel davranış olarak ele alınan duygusal emek davranışları Ashforth ve Humphrey'in 1993 yılında yaptıkları çalışmalarında bu iki davranışa ek olarak samimi davranışı eklemeleriyle birlikte üç alt başlıkta ele alınmaya başlanmıştır.

\section{Yüzeysel Davranış}

Yüzeysel rol yapma olarak da ifade edilen yüzeysel davranış, çalışanların örgüt tarafından istenilen duyguları yüz ifadelerinde, jest ve mimiklerinde ya da ses tonlarında değişiklik yaparak hissediyormuş gibi yansıtmaları olarak tanımlanabilir (Chu ve Murrman, 2006, s.1182). Zira çalışanlar kendi duygularına değil işlerinin gerektirdiği davranışlara odaklanmaktadır (Hochschild,1983). Aslında bu durum çalışanların gerçek duyguları ile yansıttıkları hisler arasında bir uyumsuzluk olduğu anlamına da gelir. Bu nedenle yüzeysel davranış için duygusal uyumsuzluk/çelişki kavramı da kullanılmaktadır (Grandey, 2003, s.87). Yüzeysel davranış, olumsuz duyguların bastırılıp olumlu duygular içindeymiş gibi davranmak olarak da tanımlanabilir. Çünkü, çalışanlardan genelde müşterilerine güler yüzlü davranmaları ve onlara karşı olumlu tavırlar sergilemeleri istenir (Diefendorff vd., 2005, s.340). Ancak bu durum çalışanlarda; iş stresi, rol belirsizliği ya da duygusal tükenme gibi bir takım sorunlar doğurabilir (Pugliesi ve Karen, 1999, s.130).

\section{Derinlemesine Davranış}

Derinlemesine davranış, çalışanların beklenen davranışları gerçekten hissedebilmek için kendilerini zorlamaları olarak tanımlanabilir (Diefendorff, vd. 2005:340). Çünkü derinlemesine davranışta, yüzeysel davranışta olduğu gibi hissedilen duygu ve davranışlar arasında bir çelişki yoktur. Dahası çalışanlar bu duyguları gerçekten hissetme çabası içindedir (Kocabaş, 2014, s.13). Bu nedenledir ki; literatürde derinlemesine davranış için duygusal çaba kavramı da kullanılmaktadır. Hochschild ise; derinlemesine davranışı, pasif ve aktif derinlemesine davranış olarak ikiye ayırmaktadır. Yazara göre; bireyler istenilen duyguyu hissetmek için bir çaba içindeyse ve kendini o duyguyu hissetmek için ikna etmeye çalışıyorsa aktif derinlemesine 
davranış içersindedir. Ancak söz konusu duygular herhangi bir çabaya ihtiyaç duyulmadan çalışanlar tarafından hissedilebiliyorsa pasif derinlemesine davranış söz konusudur (Kızanlıklı,2014, s.21).

\section{Samimi Davranış}

Ashforth ve Humphrey'e göre; çalışanların onlardan beklenen davranışları yerine getirebilmeleri için her zaman rol yapmalarına gerek yoktur. Kimi zaman sergilemeleri beklenen duygular çalışanların gerçek duyguları olabilir (1993, s.94). Dolayısıyla samimi davranış, çalışanların hizmet sunarken, örgütün beklediği ya da işin gerektirdiği davranışların bir rol sonucu ya da örgüt istediği için değil de çalışanların kendi içinden geldiğinde ve samimi duygular ile hissettiğinde sergilenmesidir (Bıylk, 2014, s.24).

\section{Veri Toplama Aracı ve Yöntemi}

$\mathrm{Bu}$ çalışma, Türkiye'de sağlık alanında yapılmış duygusal emek ile ilgili araştırmalara yönelik bir literatür incelemesidir. Çalışma kapsamında, uygun veri kaynakları kullanılarak duygusal emek ile ilgili yapılan araştırmalar belirlenmiş ve belirlenen ölçütler doğrultusunda elemeler yapılmıştır. Elemeler sonucunda değerlendirilmeye alınan araştırmalar; yazarı, yayın yıll, örneklem seçimi, araştırma türü ve elde edilen sonuçları bakımından incelenmiştir.

Duygusal emek ile ilgili Türkiye'de ve sağlı alanında yapılan araştırmaların tamamına ulaşabilmek için arama motoru olarak; YÖK Tez Arama Merkezi, Ulakbim, Google Akademik, Sciencedirect, Scopus, Ebscohost ve Asosindex kullanılmıştır. Kullanılan anahtar kelimeler, arama kriterleri ve araştırmanın sınırlılıkları aşağıdaki tabloda verilmiştir. 
Tablo 1. Araştırma Tarama Kriterleri

\begin{tabular}{|c|c|}
\hline $\begin{array}{l}\text { Veri } \\
\text { Tabanları }\end{array}$ & $\begin{array}{l}\text { - YÖK Tez Arama Merkezi } \\
\text { - Ulakbim } \\
\text { - Google Akademik } \\
\text { - Sciencedirect } \\
\text { - Scopus } \\
\text { - Ebscohost } \\
\text { - Asosindex }\end{array}$ \\
\hline $\begin{array}{l}\text { Anahtar } \\
\text { Kelimeler }\end{array}$ & $\begin{array}{l}\text { - Duygusal Emek } \\
\text { - Emotional Labour } \\
\text { - Emotional Labor }\end{array}$ \\
\hline $\begin{array}{l}\text { Arama } \\
\text { Kriterleri }\end{array}$ & $\begin{array}{l}\text { - Araştırmanın Türkiye'de yapılmış olması. } \\
\text { - Türkçe ya da İngilizce yazıımışolması. } \\
\text { - Yapılan çalışmaların sağılık alanında veya hemşireler, hekimler ya da sağlık } \\
\text { çalışanları üzerinde yapılmış olması. } \\
\text { - Mart 2017’ye kadar yayımlanmış bir araştırma olması. } \\
\text { - Tez ya da yayımlanmış makale olması. }\end{array}$ \\
\hline
\end{tabular}

Tablo 1'de belirtilen anahtarlar kelimeler ve arama kriterleri doğrultusunda yapılan tarama sonucunca toplam 23 çalışma tespit edilmiştir. Ancak yazarları tarafından erişim kısıtlaması konulduğu için, 4 tezin tam metinlerine ulaşılamamıştır. Ayrıca Türkay ve arkadaşlarının (2011, s. 210) ve Ünlü ve Yürür'ün (2011, s. 192) hizmet sektöründe duygusal emek konulu çalışmaları sağlık çalışanlarını kapsasa da sadece sağlık alanına yönelik bir çalışma olmadıkları için bu çalışmaya dahil edilmemiştir.

Çalışmaya dahil edilen ve tam metnine ulaşılan araştırmalar ise; yazarı, araştırma örneklemi ve sonuçları bakımından aşağıdaki tabloda verilmiştir.

Tablo 2. Çalışma Kapsamına Alınan Duygusal Emek Konulu Çalışmalar

\begin{tabular}{|c|c|c|c|c|c|c|}
\hline No & $\begin{array}{l}\text { Yazar(lar)/ } \\
\text { Tarih }\end{array}$ & Araştırma İsmi & Türü & Örneklemi & Araştırma Yöntemi & Sonuç \\
\hline 1 & $\begin{array}{l}\text { (Değirmenci, } \\
\text { 2010) }\end{array}$ & $\begin{array}{l}\text { Hemşirelerin Duygusal } \\
\text { Emek Davranışı Ve } \\
\text { Etkileyen Faktörler }\end{array}$ & $\begin{array}{l}\text { Y. Lisans } \\
\text { Tezi }\end{array}$ & Hemşireler & $\begin{array}{l}\text { Duygusal Emek } \\
\text { Davranışları Ölçeği }\end{array}$ & $\begin{array}{l}\text { Hemşirelerin ch çok } \\
\text { derinlemesine, en az ise bastırma } \\
\text { davranışını kullandıkları ve } \\
\text { duygusal emek davranış ölçeğinin } \\
\text { üç alt boyutu olan derinlemesine, } \\
\text { rol yapma ve bastırma } \\
\text { davranışları ile } \quad \text { bağımsız } \\
\text { değişkenler arasında anlamlı } \\
\begin{array}{l}\text { ilişkilerin olduğu } \\
\text { saptanmıştır. }\end{array} \\
\end{array}$ \\
\hline
\end{tabular}




\begin{tabular}{|c|c|c|c|c|c|c|}
\hline 2 & (Çaldağ, 2010) & $\begin{array}{lr}\text { Duygusal } & \text { Emek } \\
\text { Davranışlarının } & \text { Sağılık } \\
\text { Çalışanlarında } & \text { İş } \\
\text { Sonuçlarına Etkileri } & \end{array}$ & $\begin{array}{l}\text { Y. Lisans } \\
\text { Tezi }\end{array}$ & $\begin{array}{l}\text { Sağlık } \\
\text { Çalışanları }\end{array}$ & $\begin{array}{l}\text { Duygusal } \\
\text { Ölçeği }\end{array}$ & $\begin{array}{l}\text { Duygusal emek öncüllerinden } \\
\text { müşteri etkileşim beklentileri, } \\
\text { denetleyici desteği ve iş } \\
\text { arkadaşları desteği, duygusal } \\
\text { emek davranışları üzerinde pozitif } \\
\text { yönde etkiye sahip bulunmuştur. }\end{array}$ \\
\hline 3 & $\begin{array}{l}\text { (Köse vd., } \\
\text { 2011) }\end{array}$ & $\begin{array}{l}\text { Duygusal Emek } \\
\text { Davranışlarının } \\
\text { İşgörenlerin Tükenmişlik } \\
\text { Düzeyleri İle illişkisi Üzerine } \\
\text { Sağlık Sektöründe Bir } \\
\text { Araştırma }\end{array}$ & Araştırma & Hekimler & $\begin{array}{l}\text { Duygusal Emek } \\
\text { Ölçeği; Maslach } \\
\text { Tükenmişlik } \\
\text { Envanteri }\end{array}$ & $\begin{array}{l}\text { Kamu sektöründe çalışanların } \\
\text { yüzeysel davranış gösterme ve } \\
\text { duygusal çaba harcama } \\
\text { boyutlarında özel sektördekilere } \\
\text { oranla daha yüksek ortalamalara } \\
\text { sahip oldukları görülmüştür. }\end{array}$ \\
\hline 4 & $\begin{array}{l}\text { (Oral vd., } \\
\text { 2011) }\end{array}$ & $\begin{array}{l}\text { Hekimlerin Duygusal Emek } \\
\text { Kullanımı Ile Iş̧ Doyumu Ve } \\
\text { Tükenmişlik Düzeyleri } \\
\text { Arasındaki İlişkiler Üzerine } \\
\text { Bir Araştırma }\end{array}$ & Araştırma & Hekimler & $\begin{array}{l}\text { Duygusal Emek } \\
\text { Ölçeği; } \\
\text { İş Doyumu Ölçeği; } \\
\text { Tükenmişlik Ölçeği }\end{array}$ & $\begin{array}{l}\text { Buna göre, kamu sektöründe } \\
\text { çalışanlar özel sektördekilere } \\
\text { oranla daha fazla yüzeysel } \\
\text { davranış göstermekte ve daha } \\
\text { fazla duygusal } \\
\text { harcamaktadırlar. Elde edilen } \\
\text { sonuçlar literatürle ters } \\
\text { düşmemektedir. }\end{array}$ \\
\hline 5 & (Onay, 2011) & $\begin{array}{l}\text { Çalışanın Sahip Olduğu } \\
\text { Duygusal Zekâsının Ve } \\
\text { Duygusal Emeğinin, Görev } \\
\text { Performansı Ve Bağlamsal } \\
\text { Performans Üzerindeki } \\
\text { Etkisi }\end{array}$ & Araştırma & Hemşireler & $\begin{array}{l}\text { Duygusal } \\
\text { Ölçeği }\end{array}$ & $\begin{array}{l}\text { Çalışanların özellikle iş } \\
\text { yaşamlarında yaptıkları işe } \\
\text { yönelik "derin davranış" } \\
\text { sergilemeleri yönünde kendilerini } \\
\text { geliştirmeleri ve duygusal zekâ } \\
\text { boyutları arasında bulunan temel } \\
\text { faktörleri etkin bir şekilde } \\
\text { yönetme becerisine sahip } \\
\text { olmaları durumunda "iş } \\
\text { performanslarında da olumlu } \\
\text { gelişmeler olacaktır. }\end{array}$ \\
\hline 6 & (Tunç, 2012) & $\begin{array}{lr}\text { Yoğun } & \text { Bakım } \\
\text { Hemşirelerinin } & \text { Hastalarla } \\
\text { Illişkilerinde } & \text { Duygusal } \\
\text { Emek Olarak Empati }\end{array}$ & $\begin{array}{l}\text { Y. Lisans } \\
\text { Tezi }\end{array}$ & Hemşireler & $\begin{array}{lr}\text { Duygusal } & \text { Emek } \\
\text { Ölçeği; } & \text { Empatik } \\
\text { Eğilim Ölçeği }\end{array}$ & $\begin{array}{l}\text { Yoğun bakım hemşirelerinin } \\
\text { empati düzeylerinin daha yüksek } \\
\text { olmadığı, duygusal emek } \\
\text { stratejilerinden derinlemesine } \\
\text { davranışı daha fazla } \\
\text { kullanmadıkları ve yaşam kalitesi } \\
\text { algılamalarının daha olumsuz } \\
\text { olduğunu göstermiştir. }\end{array}$ \\
\hline 7 & $\begin{array}{l}\text { (Kaya ve } \\
\text { Tekin, 2013) }\end{array}$ & $\begin{array}{l}\text { Duygusal Emek Kavramı } \\
\text { Çerçevesinde Sağlıkta } \\
\text { Yeniden Yapılanma }\end{array}$ & Derleme & - & - & $\begin{array}{l}\text { Duygusal emek konusunda } \\
\text { yabancı literatürde çok sayıda } \\
\text { kuramsal ve uygulamalıçalışmalar } \\
\text { bulunmasına karşın ülkemizde bu } \\
\text { alandaki çalışmalar oldukça yeni } \\
\text { ve sınırlı sayıdadır. }\end{array}$ \\
\hline 8 & $\begin{array}{l}\text { (Yıldırım ve } \\
\text { Erul, 2013) }\end{array}$ & $\begin{array}{lr}\text { Duygusal } & \text { Emek } \\
\text { Davranışının } & \text { İşgörenlerin } \\
\text { Tükenmişlik } & \text { Düzeylerine } \\
\text { Etkisi } & \\
\end{array}$ & Araştırma & Hemşireler & $\begin{array}{l}\text { Maslach } \\
\text { Tükenmişlik Ölçeği; } \\
\text { Duygusal Emek } \\
\text { Davranışları Ölçeği }\end{array}$ & $\begin{array}{l}\text { Duygusal emek davranışı ile } \\
\text { tükenmişlik düzeyleri arasında } \\
\text { anlamlı bir ilişki bulunmuştur. }\end{array}$ \\
\hline 9 & $\begin{array}{l}\text { (Öğüt, } \\
\text { 2013) }\end{array}$ & $\begin{array}{l}\text { A Research To Determine } \\
\text { The Effects Of Emotional } \\
\text { Labour On Emotional } \\
\text { Exhaustion And Job } \\
\text { Satisfaction: The Case Of } \\
\text { Health Institutions }\end{array}$ & Araştırma & $\begin{array}{l}\text { Sağlık } \\
\text { Çalışanları }\end{array}$ & $\begin{array}{l}\text { Duygusal } \\
\text { Ölçeği }\end{array}$ & $\begin{array}{l}\text { Çalışanların duygusal emek ve } \\
\text { duygusal tükenmişlikleri arasında } \\
\text { istatistiksel olarak anlamlı bir ilişki } \\
\text { vardır. }\end{array}$ \\
\hline 10 & $\begin{array}{l}\text { (Çağlıyan, vd, } \\
\text { 2013) }\end{array}$ & $\begin{array}{l}\text { A Consideration On } \\
\text { Emotional Labour, } \\
\text { Burnout Syndrome And } \\
\text { Job Performance: The Case } \\
\text { Of Health Institutions }\end{array}$ & Araştırma & $\begin{array}{l}\text { Sağlık } \\
\text { Çalışanları }\end{array}$ & $\begin{array}{l}\text { Duygusal Emek } \\
\text { Ölçeği; } \\
\text { Tükenmişlik Ölçeği }\end{array}$ & $\begin{array}{l}\text { Duygusal emek seviyeleri ile } \\
\text { çalışma performansları arasında } \\
\text { anlamlı bir ilişki bulunmuştur. }\end{array}$ \\
\hline 11 & (Serin, 2014) & $\begin{array}{l}\text { Duygusal Emeğin } \\
\text { Tükenmişlik Ve Iş̧ } \\
\text { Tatminine Etkisi: Sağlık } \\
\text { Sektöründe Bir Uygulama }\end{array}$ & $\begin{array}{l}\text { Y. Lisans } \\
\text { Tezi }\end{array}$ & $\begin{array}{l}\text { Sağlık } \\
\text { Çalışanları }\end{array}$ & $\begin{array}{l}\text { Duygusal Emek } \\
\text { Ölçeği }\end{array}$ & $\begin{array}{l}\text { Cinsiyete göre duygusal emek } \\
\text { değerlendirildiğinde kadınların } \\
\text { erkeklere göre daha samimi } \\
\text { davranışlar } \\
\text { görülmüştür. }\end{array}$ \\
\hline 12 & $\begin{array}{l}\text { (Tunç, } \\
\text { 2014) }\end{array}$ & $\begin{array}{lr}\text { Yoğun Bakım Ve } \text { Yataklı } \\
\text { Servis } \quad \text { Hemşirelerinde } \\
\text { Duygusal } & \text { Emek } \\
\text { Stratejilerinin } & \text { Empatik } \\
\text { Eğilim } & \text { Açısından } \\
\text { İncelenmesi } & \end{array}$ & Araştırma & Hemşireler & $\begin{array}{lr}\text { Duygusal } & \text { Emek } \\
\text { Ölçeği; } & \text { Empatik } \\
\text { Eğilim Ölçeği }\end{array}$ & $\begin{array}{l}\text { Yoğun bakım hemşirelerinin } \\
\text { empati eğilimlerinin daha yüksek } \\
\text { olmadığı ve duygusal emek } \\
\text { stratejilerinden derinlemesine } \\
\text { davranışı ve duygusal çabayı daha } \\
\text { fazla kullanmadıkları } \\
\text { bulunmuştur. }\end{array}$ \\
\hline 13 & $\begin{array}{l}\text { (Ozturk, vd, } \\
\text { 2015) }\end{array}$ & $\begin{array}{l}\text { Emotional Labor Levels Of } \\
\text { Nurse Academicians }\end{array}$ & Araştırma & Hemşireler & $\begin{array}{l}\text { Duygusal } \\
\text { Ölçeği }\end{array}$ & $\begin{array}{l}\text { Çalışanların duygusal seviyeleri ve } \\
\text { bu faktörler onların duygusal } \\
\text { emek düzeylerini etkilemektedir. }\end{array}$ \\
\hline
\end{tabular}




\begin{tabular}{|c|c|c|c|c|c|c|}
\hline 14 & $\begin{array}{l}\text { (Anafarta, } \\
2015 \text { ) }\end{array}$ & $\begin{array}{l}\text { Job Satisfaction As A } \\
\text { Mediator Between } \\
\text { Emotional Labor And The } \\
\text { Intention To Quit }\end{array}$ & Araştırma & $\begin{array}{l}\text { Sağılık } \\
\text { Çalışanları }\end{array}$ & $\begin{array}{l}\text { Duygusal } \\
\text { Ölçeği }\end{array}$ & $\begin{array}{l}\text { Ifade edilen duygular ile iş } \\
\text { doyumu arasında herhangi bir } \\
\text { ilişki bulunamamıştır. İ̧̧ doyumu, } \\
\text { duygusal emek ve iş bırakma } \\
\text { niyeti arasındaki ilişki de önemli } \\
\text { ölçüde aracılık rolü üstlenir. }\end{array}$ \\
\hline 15 & $\begin{array}{l}\text { (Beğenirbaş, } \\
\text { 2015) }\end{array}$ & $\begin{array}{l}\text { Psikolojik Sermayenin } \\
\text { Çalışanların } r \text { Duygu } \\
\text { Gösterimleri Ve Işe } \\
\text { Yabancılaşmalarına } \\
\text { Etkileri: Sağlık Sektöründe } \\
\text { Bir Araştırma }\end{array}$ & Araştırma & $\begin{array}{l}\text { Sağlık } \\
\text { Çalışanları }\end{array}$ & $\begin{array}{l}\text { Duygusal } \\
\text { Ölçeği }\end{array}$ & $\begin{array}{l}\text { Psikolojik sermayenin duygusal } \\
\text { emek alt boyutları ile işe } \\
\text { yabancılaşma üzerinde önemli } \\
\text { etkilere sahip olduğu } \\
\text { görülmüşstür. Ayrıca katııımcıların } \\
\text { duygusal emeklerinin psikolojik } \\
\text { sermaye ve işe yabancılaşma } \\
\text { arasında anlamlı aracılık rolüne } \\
\text { rastlanılmamışıtı. }\end{array}$ \\
\hline 16 & $\begin{array}{l}\text { (Kesen ve } \\
\text { Akyüz, 2016) }\end{array}$ & $\begin{array}{l}\text { Duygusal Emek Ve } \\
\text { Prososyal Motivasyonun } \\
\text { işe Gömülmüşlüğe Etkisi: } \\
\text { Sağlık Çalışanları Üzerine } \\
\text { Bir Uygulama }\end{array}$ & Araştırma & $\begin{array}{l}\text { Sağlık } \\
\text { Çalışanları }\end{array}$ & $\begin{array}{l}\text { Duygusal Emek } \\
\text { Ölçeği; Prososyal } \\
\text { Motivasyon Ölçeği; } \\
\text { İşe Gömülmüşlük } \\
\text { Ölçeği }\end{array}$ & $\begin{array}{l}\text { Duygusal emeğin derinden rol } \\
\text { yapma ve doğal duygular boyutu } \\
\text { çalışanların prososyal } \\
\text { motivasyonunu arttırıken } \\
\text { yüzeysel rol yapma boyutu } \\
\text { prososyal motivasyonu anlaml } \\
\text { bir şekilde etkilememektedir. }\end{array}$ \\
\hline 17 & $\begin{array}{l}\text { (Naktiyok ve } \\
\text { Ağırman, } \\
\text { 2016) }\end{array}$ & $\begin{array}{l}\text { İş Odaklı Duygusal Emek } \\
\text { Ve Duygusal Tükenme } \\
\text { Arasındaki Ilişskide Çalışan } \\
\text { Odaklı Duygusal Emek Ve } \\
\text { Mesleki Bağılı̆̆ın Aracılık } \\
\text { Etkisi }\end{array}$ & Araştırma & Hemşireler & $\begin{array}{l}\text { İş Odakı Duygusal } \\
\text { Emek Ölçeği }\end{array}$ & $\begin{array}{l}\text { Duygusal emek ve duygusal } \\
\text { tükenmişlik arasındaki ilişkiyi ele } \\
\text { alan daha önceki araştırmalardan } \\
\text { farklı olarak mesleki bağlıığın bu } \\
\text { ilişkideki rolü vurgulanmakta ve } \\
\text { elde edilen sonuçlar, ilgili literatür } \\
\text { kapsamında tartışılmaktadır. }\end{array}$ \\
\hline 18 & $\begin{array}{l}\text { (Çelik ve Yıldız, } \\
\text { 2016) }\end{array}$ & $\begin{array}{l}\text { Duygusal Emek Düzeyinin } \\
\text { İşten Ayrılma Niyeti } \\
\text { Üzerindeki Etkisinde } \\
\text { Stresin Aracı Rolü }\end{array}$ & Araştırma & Hemşireler & $\begin{array}{l}\text { Duygusal Emek } \\
\text { Ölçeği; } \\
\text { Işten Ayrılma Niyeti } \\
\text { Ölçeği; } \\
\text { İş Stresi Ölçeği }\end{array}$ & $\begin{array}{l}\text { Yüzeysel rol yapmanı stresi ve } \\
\text { işten ayrılma niyetini pozitif ve } \\
\text { anlamlı olarak etkilediği, doğal } \\
\text { duygular sergilemenin ve stresin } \\
\text { işten ayrılma niyetini anlamlı } \\
\text { olarak etkilediği ve yüzeysel rol } \\
\text { yapmanın işten ayrılma niyeti } \\
\text { üzerindeki etkisinde stresin aracı } \\
\text { rolünün bulunduğu tespit } \\
\text { edilmiştir. }\end{array}$ \\
\hline 19 & $\begin{array}{l}\text { (Değirmenci, } \\
\text { 2016) }\end{array}$ & $\begin{array}{l}\text { Hemşireler İçin Duygusal } \\
\text { Emek Davranışı Ölçeğinin } \\
\text { Geliştirilmesi }\end{array}$ & $\begin{array}{l}\text { Doktora } \\
\text { Tezi }\end{array}$ & Hemşireler & - & $\begin{array}{l}\text { "Hemşirelerin Duygusal Emek } \\
\text { Davranışı Ölçeği" isimli } 24 \text { madde } \\
\text { ve 5'li Likert tipinde } 3 \text { alt boyuttan } \\
\text { oluşan bir ölçek geliştirilmiştir. }\end{array}$ \\
\hline
\end{tabular}

\section{Bulgular}

Bu bölümde değerlendirmeye alınan araştırmalara ilişkin bulgular yer almaktadır. Belirlenen kriterler çerçevesinde yapılan tarama sonucunda 23 çalışma bulunmuştur. Bu çalışmaların 6’sı yüksek lisans tezi, 3'ü ise doktora tezidir. Ancak 4 çalışmanın tam metnine yazarları tarafından erişim kısıtlanması konulduğu için ulaşılamamıştır. Tespit edilen çalışmaların 14'ü ise makaledir. Ancak bu makalelerin 13'ü araştırma makalesi, 1'i ise derlemedir.

Tablo 3. Araştırmaya Alınan Çalışmaların Türlere Göre Dağılımı

\begin{tabular}{|l|c|c|}
\hline Çalışma Türü & Sayı & \% \\
\hline Yüksek Lisans $\left(6^{*}\right)$ & 4 & 21,06 \\
\hline Doktora (3*) & 1 & 5,26 \\
\hline Makale & 14 & 73,68 \\
\hline Toplam (23*) & $\mathbf{1 9}$ & $\mathbf{1 0 0 , 0 0}$ \\
\hline
\end{tabular}

* Tam metnine ulaşılamayan çalışmalar da dahil edildiğinde. 


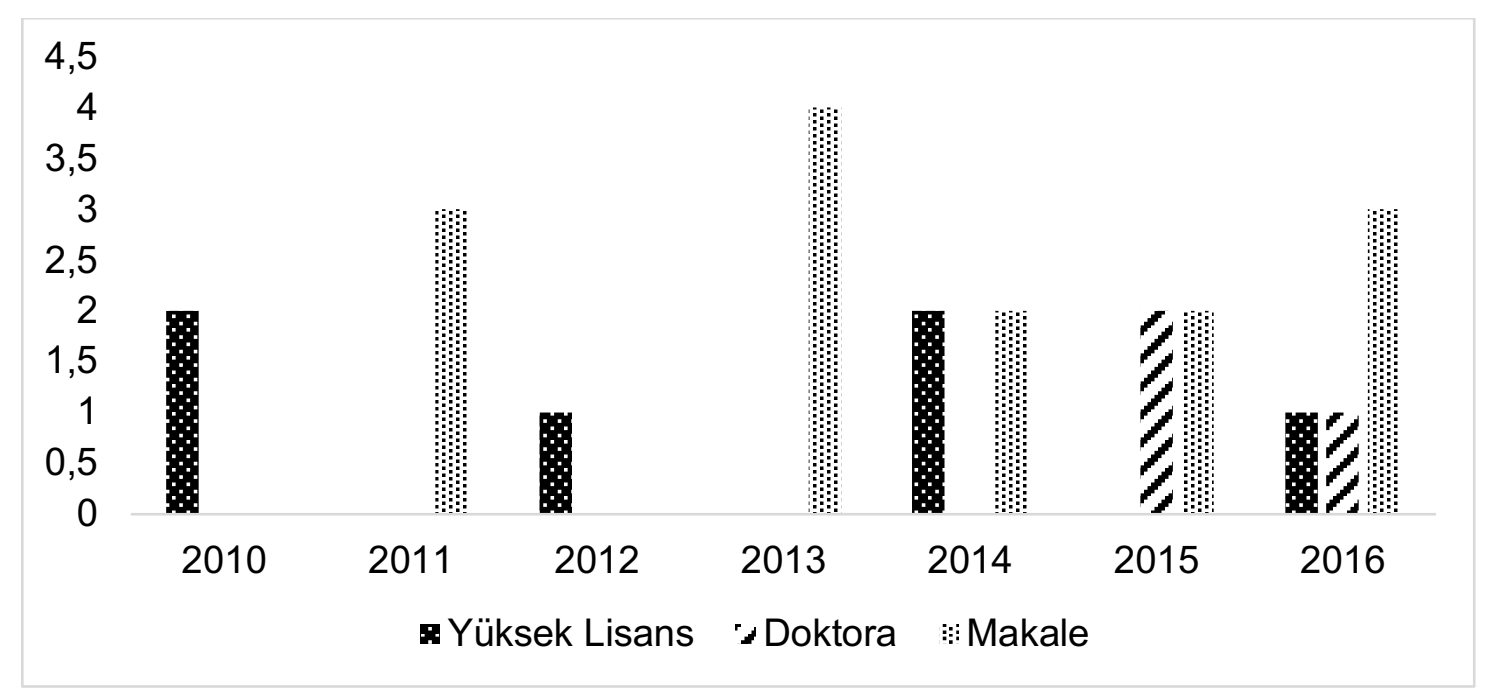

Şekil 2. Duygusal Emek Konulu Araştırmaların Türlere ve Yıllara Göre Dağılımları

Çalışma kapsamında ele alınan araştırmaların yıllara ve türlerine göre dağılımı incelendiğinde ise (tam metnine ulaşılamayan çalışmalar da dahil olmak üzere); Türkiye'de sağlık alanında yapılmış duygusal emek konusu ile ilgili ilk çalışma 2010 yılında yüksek lisans tezi olarak yapılmıştır. 2010 yılı itibari ile her yıl en az iki çalışma yapıldığı görülmektedir (bknz. Şekil 2). Literatür incelendiğin de duygusal emek kavramının 1980'li yıllara kadar uzandığı görülmektedir. Ancak ülkemizde sağlık alanında bu konuya yönelilk ilk çalışma 2010 yılında yapılabilmiştir. Dolayısıyla sağlık alanın da duygusal emek konulu yeni ve kapsamlı araştırmaların yapılmaya ihtiyaç duyulduğu söylenebilir.

Tablo 4. Değerlendirmeye Alanına Makalelerde Kullanılan Anahtar Kelimeler

\begin{tabular}{|l|c|c|}
\hline Anahtar Kelimeler & Sayı & \% \\
\hline $\begin{array}{l}\text { Duygusal Emek } \\
\text { (Iş Odaklı Duygusal Emek, Çalışan Odaklı Duygusal Emek) }\end{array}$ & 14 & 26,93 \\
\hline $\begin{array}{l}\text { Tükenmişlik } \\
\text { (Duygusal Tükenmişlik, Tükenmişlik Sendromu) }\end{array}$ & 5 & 9,62 \\
\hline İşen Ayrılma Niyeti & 3 & 5,76 \\
\hline Yüzeysel Davranış & 3 & 5,76 \\
\hline Derinlemesine Davranış & 3 & 5,76 \\
\hline Sağlık Çalışanları & 2 & 3,85 \\
\hline Görev ve Bağlamsal Performans & 2 & 3,85 \\
\hline İş Tatmini & 2 & 3,85 \\
\hline Stres & 1 & 1,92 \\
\hline Diğer & 17 & 32,70 \\
\hline Toplam & $\mathbf{5 2}$ & $\mathbf{1 0 0 , 0 0}$ \\
\hline
\end{tabular}


Tablo 4'de araştırma kapsamında değerlendirmeye alınan makalelerde kullanılan anahtar kelimeler verilmiştir. İncelenen 14 makalede, \% 26,93 (14) ile en çok kullanılan anahtar kelimenin duygusal emek olduğu görülmektedir. 13 kullanımdan birinde "iş odaklı duygusal emek" birinde ise "çalışan odaklı duygusal emek" kavramlarının kullanıldığı tespit edilmiştir. 14 makalede duygusal emek kavramından sonra en sık kullanılan anahtar kelimenin ise \% 9,62 (5) ile tükenmişlik olduğu görülmektedir. Ayrıca işten ayrılma niyeti ve davranış çeşitlerinin de sıklıkla kullanıldı̆̆ söylenebilir.

Tablo 5. Çalışma Kapsamındaki Araştırmaların Örneklem Seçimleri

\begin{tabular}{|l|c|c|}
\hline Örneklem & Sayı & \% \\
\hline Hemşireler & 9 & 30,00 \\
\hline Sağlık Çalışanları & 7 & 38,88 \\
\hline Hekimler & 2 & 11,12 \\
\hline Toplam & $\mathbf{1 8 *}$ & $\mathbf{1 0 0 , 0 0}$ \\
\hline
\end{tabular}

Çalışma kapsamında alınan araştırmaların çalışma grupları incelendiğinde ise; çalışmaların \% 50,00'sinin hemşireler üzerinde yapıldığı görülmektedir. Çalışmaların \% 38,88'inde ise genel olarak sağlık çalışanları çalışmaya dahil edilmiştir. Ancak Hochschild 1983 yılında yaptığı çalışmasında duygusal emek gerektiren meslek grupları arasında yöneticileri de saymış olsa da, henüz ülkemizde sağlık alanında yapılmış ve sağlık yöneticilerinin çalışmaya dahil edildiği bir çalışma tespit edilememiştir.

Tablo 6. Araştırmalarda Kullanılan Soru Formları

\begin{tabular}{|c|c|c|c|}
\hline Kişi & Soru Formaları & Sayı & $\%$ \\
\hline Grandey (2003) & Duygusal Emek Ölçeği & 6 & 33,33 \\
\hline Diefendorff (2005) & Duygusal Emek Ölçeği & 5 & 27,77 \\
\hline Brotheidg and Lee (1998) & Duygusal Emek Ölçeği & 2 & 11,11 \\
\hline Basım ve Demirbaş (2012) & Duygusal Emek Ölçeği & 2 & 11,11 \\
\hline Pala and Tepeci (2009) & Duygusal Emek Ölçeği & 1 & 5,57 \\
\hline \multicolumn{2}{|c|}{ Soru formu araştırmacı tarafından hazırlanan } & 2 & 11,11 \\
\hline \multicolumn{2}{|l|}{ Toplam } & $18^{*}$ & 100,0 \\
\hline
\end{tabular}

Çalışma kapsamında değerlendirmeye alının 18 araştırmada duygusal emeği ölçmek için kullanılan soru formlarına bakıldığında ise (Tablo 6); \% 33,33 ile (6) en çok kullanılan ölçeğin Grandey tarafından 2003 yılında geliştirilen “duygusal emek ölçeği” olduğu görülmektedir. Ayrıca çalışmaların 2'sinde kullanılan soru formları yazarları tarafından literatür incelemesi yapılarak hazırlanmıştır. 


\section{Sonuç}

Literatür incelendiğinde duygusal emek kavramının, ilk kez Hochschild tarafından 1979 yılında kullanıdığı görülmektedir. Hochschild çalışmasında duygusal emek kavramını 2 temel mekanizmada ele almıştır. Ancak Ashforth ve Humphrey, 1993 yılında yaptıkları çalışmalarında, gerçek/samimi davranış dedikleri boyutu ekleyerek duygusal emeği; yüzeysel davranış, derinlemesine davranış ve samimi davranış olarak üç temel boyutta tanımlamışlardır.

Literatürde bu iki temel yaklaşımın yanı sıra kullanılan farklı duygusal emek yaklaşımları da vardır. Bunlar Morris ve Fieldman'ın (1996) ve Grandey'in (2000) yaklaşımlarıdır. Sonuç itibariyle duygusal emek kavramı yıllar itibariyle bir çok yazar tarafından ele alınmış ve farklı açılardan incelenmiştir. Ancak literatürde sıklıkla bu dört yaklaşıma atıf yapılmaktadır.

Her ne kadar bu alanda yapılan çalışmalar 1980'li yıllara dayansada, ülkemizde ilk duygusal emek çalışmaları 2000'li yılların başlarında yapılmıştır. Dolayısıyla söz konusu kavramın ülkemiz için henüz yeni bir kavram olduğu ve bu alanda yeni çalışmaların yapılması gerektiği söylenebilir.

Literatür incelemesi yapıldığında Türkiye'de sağlık alanında yapılmış 23 çalışma tespit edilmiştir. Ancak bu çalışmalardan 4'ünün tam metnine yazarları tarafından erişim kısıtlaması konulduğu için ulaşılamamıştır. Yine bu çalışmalar incelendiğinde ilk çalışmanın 2010 yılında yüksek lisans tezi olarak yapıldı̆̆ görülmektedir. Takip eden yıllar da ise farklı türden çalışmalar yapılmış dahi olsa henüz sağlık alanında yapılan çalışmalarında az olduğu söylenebilir.

Ayrıca ele alınan çalışmaların örneklemleri incelendiğinde ise \% 50,00 ile ilk sırada hemşireler gelmektedir. Değirmenci 2010 yılında yaptığı çalışmasında, hemşirelerin en çok derinlemesine davranış gösterdiklerini tespit etmiştir. Tunç ise, 2012 yılında yaptığı çalışmasında, yoğun bakımda çalışan hemşirelerin derinlemesine davranışı çok sık kullanmadıklarını bulmuştur. Dolayısıla hemşirelerin çalışmış oldukları birime göre duygusal emek düzeylerinin ve davranışlarının değişkenlik gösterdiği görülmektedir.

Değerlendirilmeye alınan çalışma sonuçlarına bakıldığında; kadınların erkeklere göre daha samimi davranışlar gösterdiği (Serin, 2014), çalışanların duygusal seviyelerinin duygusal emek davranışlarını etkilediği (Öztürk vd, 2015), duygusal emek düzeyi ile çalışma performansı arasında bir istatistiksel olarak anlamlı bir ilişki olduğu (Çağlıyan vd, 2013; Onay, 2011) ve kamu sektöründe çalışanların özel sektördekilere oranla daha yüksel yüzeysel davranış gösterme eğiliminde oldukları (Köse, 2011; Oral, 2011) görülmektedir.

Yönetim literatürü incelendiğinde, Hochschild 1983 yılında yaptığ çalışmasında yöneticileri duygusal emek sergilemesi gereken meslekler arasında saymıştır. Ancak yapılan araştırma sonucunda henüz ülkemizde sağlık yöneticilerine yönelik olarak yapılmış duygusal emek konulu herhangi bir araştırma tespit edilememiştir. 


\section{Kaynakça}

Anafarta, N. (2015). Job satisfaction as a mediator between emotional labor and the intention to quit. International Journal of Business and Social Science, 6(2), http://ijbssnet.com/journals/Vol_6_No_2_February_2015/11.pdf.

Ashforth, B. E. \& Humphrey, R. H. (1993). Emotional labor in service roles: The influence of identity, Academy of Management Review, 18(1), 88-115, http://www.jstor.org/stable/pdf/258824.pdf.

Basım H. \& Begenirbaş, M. (2012). Çalışma yaşamında duygusal emek: Bir ölçek uyarlama çalışması yönetim ve ekonomi. Celal Bayar Üniversitesi İktisadi ve İdari Bilimler Fakültesi Dergisi, 19

$(1)$

77-90, http://www2.bayar.edu.tr/yonetimekonomi/dergi/pdf/C19S12012/77_90.pdf.

Beğenirbaş, M. (2015). Psikolojik sermayenin çalışanların duygu gösterimleri ve işe yabancılaşmalarına etkileri: Sağlık sektöründe bir araştırma. Süleyman Demirel Üniversitesi, İktisadi ve İdari Bilimler Fakültesi Dergisi, 20(3), 249-263, http://dergi.iibf.deu.edu.tr/index.php/cilt1-sayi1/article/view/485.

Brotheridge, C. M. \& Lee, R. T. (2003). Development and validation of the emotional labour scale. Journal of Occupational and Organizational Psychology, 76, 365-379, https://onlinelibrary.wiley.com/doi/abs/10.1348/096317903769647229.

Bıyık, Y. (2014). Duygusal Emek İle Örgütsel Vatandaşlık Davranışı İlişkisi: Bir Araştırma, (Yayımlanmamış Yüksek Lisans Tezi). Gazi Üniversitesi/Sosyal Bilimler Enstitüsü, Ankara. https://tez.yok.gov.tr/UlusalTezMerkezi/.

Çağlıyan, V., Fındık, M. \& Doğanalp, B. (2013). A consideration on emotional labour, burnout syndrome and job performance: The case of health institutions. Mediterranean Journal Of Social Sciences, 4(10), 532. http://www.mcser.org/ journal/index.php /mjss/article/viewFile/1225/1254.

Çaldağ, M. A. (2010). Duygusal Emek Davranışlarının Sağlık Çalışanlarında İş Sonuçlarına Etkileri. (Yayımlanmamış Yüksek Lisans Tezi). Selçuk Üniversitesi/Sosyal Bilimler Enstitüsü, Konya. https://tez.yok.gov.tr/UlusalTezMerkezi/.

Çelik, M., \& Yıldız, B. (2016). Duygusal emek düzeyinin işten ayrilma niyeti üzerindeki etkisinde stresin araci rolü, Journal Of International Social Research, 9(45), http://www.sosyalarastirmalar.com/cilt9/sayi45_pdf/6iksisat_kamu_isletme/celik_mazl um_yildiz_bulent.pdf.

Chu, K. H. L. \& Murrmann, S. K. (2006). Development and validation of the hospitality emotional labor scale. Tourism Management, 27(6), 1181-1191, https://www.sciencedirect.com/science/article/pii/S0261517705001998.

Değirmenci, S. (2016). Hemşireler için Duygusal Emek Davranışı Ölçeğinin Geliştirilmesi. (Yayımlanmamış Doktora Tezi). İstanbul Üniversitesi/Sağlik Bilimleri Enstitüsü, İstanbul. https://tez.yok.gov.tr/UlusalTezMerkezi/. 
Değirmenci, S. (2010). Hemşirelerin Duygusal Emek Davranışı ve Etkileyen Faktörler. (Yayımlanmamış Yüksek Lisans Tezi). İstanbul Üniversitesi/Sağlık Bilimleri Enstitüsü, İstanbul. https://tez.yok.gov.tr/UlusalTezMerkezi/.

Diefendorff, J. M., Croyle, M. H. \& Gosserand, R. H. (2005). The dimensionality and antecedents of emotional labor strategies. Journal of Vocational Behavior, 66, 339-357, https://www.sciencedirect.com/science/article/pii/S0001879104000417.

Grandey, A. A. (2000). Emotional regulation in the workplace: A new way to conceptualize emotional labor. Journal of Occupational Health Psychology, 5(1), 95, http://psycnet.apa.org/fulltext/1999-15533-009.html.

Grandey, A. (2003). When "the show must go on": Surface and deep acting as determinants of emotional exhaustion and peer-rated service delivery. Academy of Management Journal, 46, 86-96, https://journals.aom.org/doi/abs/10.5465/30040678.

Grandey, A. A. \& Diamond, J. A. (2010). Interactions with the public: bridging job design and emotional labor perspectives. Journal of Organizational Behavior, 31(2-3), 338-350, https://onlinelibrary.wiley.com/doi/full/10.1002/job.637.

Hochschild, A. R. (1983). The Managed Heart. Berkeley: CA: University Of California Press,A. https://onlinelibrary.wiley.com/doi/abs/10.1002/pam.4050030365.

Kafadar, S. B. \& Kaygın, E. (2017). Etik liderlik ve duygusal emek ilişkisi: Kafkas Üniversitesi $\begin{array}{lllll}\text { örneği. Çukurova Üniversitesi İBF } & \end{array}$ http://dergipark.gov.tr/cuiibfd/issue/34827/387721.

Kaya, E., \& Tekin, A. (2013). Duygusal emek kavramı çerçevesinde sağlıkta yeniden yapılanma. Mehmet Akif Ersoy Üniversitesi Sosyal Bilimler Enstitüsü Dergisi, 5(8), 110-119, http://oaji.net/articles/2014/1037-1405496696.pdf.

Kesen, M. \& Akyüz, B. (2016). Duygusal emek ve prososyal motivasyonun işe gömülmüşlüğe etkisi: Sağlık çalışanları üzerine bir uygulama. Çukurova Üniversitesi Sosyal Bilimler Enstitüsü Dergisi, 25(2), http://dergipark.gov.tr/cusosbil/issue/32037/353139.

Kızanlıklı, M. (2014). Otel İşletmelerinde Duygusal Emek Öncüllerinin Belirlenmesine Yönelik Bir Araştırma. (Yayımlanmamış Doktora Tezi). Gazi Üniversitesi/Eğitim Bilimleri Enstitüsü, Ankara. https://tez.yok.gov.tr/UlusalTezMerkezi/.

Kocabaş, D., (2014). Hemşirelerde Duygusal Emek ve Örgütsel Sinizm Arasindaki İlişki: Isparta İl Merkezindeki Hastanelerde Bir Araştırma. (Yayımlanmamış Yüksek Lisans Tezi). Süleyman Demirel Üniversitesi/Sosyal Bilimleri Enstitüsü, Isparta. https://tez.yok.gov.tr/UlusalTezMerkezi/.

Köse, S., Oral, L. \& Türesin, H. (2011). Duygusal emek davranışlarının işgörenlerin tükenmişlik düzeyleri ile ilişkisi üzerine sağlı sektöründe bir araştırma. İşletme Fakültesi Dergisi, 12(2), 165-185, http://dergipark.gov.tr/download/article-file/234843.

Morris, J. A. \& Feldman, D. C. (1996). The dimensions, antecedents, and consequences of emotional labor. Academy Of Management Review, 21(4), 986-1010, https://journals.aom.org/doi/abs/10.5465/amr.1996.970407186. 
Naktiyok, A. \& Ağırman, Ü. H. (2016). İş odaklı duygusal emek ve duygusal tükenme arasindaki ilişkide çalışan odaklı duygusal emek ve mesleki bağlılığın aracılık etkisi. Atatürk Üniversitesi İktisadi Ve İdari Bilimler Dergisi, 30(4), http:/edergi.atauni.edu.tr/atauniiibd/article/view/5000179434.

Onay, M. (2011), Çalışanın sahip olduğu duygusal zekasının ve duygusal emeginin, görev performansı ve bağlamsal performans üzerindeki etkisi. Ege Akademik Bakis, 11(4), 587, https://search.proquest.com/openview/d702177c7e67dfbf26bbd1e9ef3923ff/1?pqorigsite $=$ gscholar $\& \mathrm{cbl}=136110$.

Oral, L. \& Köse, S. (2011) Hekimlerin duygusal emek kullanımı ile iş doyumu ve tükenmişlik düzeyleri arasındaki ilişkiler üzerine bir araştırma, Süleyman Demirel Üniversitesi İktisadi Ve İdari Bilimler Fakültesi Dergisi, 16(2), 463-492, http://dergipark.ulakbim.gov.tr/sduiibfd/article/viewFile/5000122312/5000112617.

Ozturk, H., Bahcecik, N., Ozcelik, S. K. \& Kemer, A. S. (2015), Emotional labor levels of nurse academicians. Procedia-Social And Behavioral Sciences, 190, 32-38, https://www.sciencedirect.com/science/article/pii/S187704281503205X.

Öğüt, A., Çağlıyan, V. \& Fındık, M. (2013). A research to determine the effects of emotıonal labour on emotional exhaustion and job satisfaction: The case of health insitutions, Mediterranean Journal of Social Sciences, 4(10), 366, http://www.mcser.org/journal/index.php/mjss/article/view/1200.

Pala, T. \& Tepeci, M. (2009). Turizm İşletmelerinde Çalışanların Duygusal Emek Düzeyi Ve Duygusal Emeğin Çalışanların Tutumlarına Etkileri. (Yayımlanmamış Yüksek Lisans Tezi). Mersin Üniversitesi/Sosyal Bilimler Enstitüsü, Mersin. https://tez.yok.gov.tr/UlusalTezMerkezi/.

Pugh, S. D. (2001). Service with a smile: Emotional contagion in the service encounter. Academy of Management Journal, 44(5), 1018-1027, https://journals.aom.org/doi/abs/10.5465/3069445.

Pugliesi, K. (1999). The consequences of emotional labor: Effects on work stress, job satisfaction, and well-being. Motivation and Emotion, 23(2), 125-154, https://link.springer.com/article/10.1023/A:1021329112679.

Seçer, H. Ş. (2005). Çalışma yaşamında duygular ve duygusal emek: sosyoloji, psikoloji ve örgüt teorisi açısından bir değerlendirme, Sosyal Siyaset Konferansları Dergisi (50), http://dergipark.gov.tr/download/article-file/9152.

Serin, S. (2014). Duygusal Emeğin Tükenmişlik ve İş Tatminine Etkisi: Sağlık Sektöründe Bir Uygulama. (Yayımlanmamış Yüksek Lisans Tezi). Türk Hava Kurumu Üniversitesi/Sosyal Bilimler Enstitüsü, https://tez.yok.gov.tr/UlusalTezMerkezi/.

Tunç, P. (2012). Yoğun Bakım Hemşirelerinin Hastalarla Ilişkilerinde Duygusal Emek Olarak Empati, 19. Ulusal Psikiyatri Kongresi, Edirne, 05-07 Eylül 2012, http://arelarsiv.arel.edu.tr:8080/xmlui/handle/123456789/403. 
Tunç, P., Gitmez, A., \& Krespi Boothby, M. R. (2014). Yoğun Bakım Ve Yataklı Servis Hemşirelerinde Duygusal Emek Stratejilerinin Empatik Eğilim Açısından Incelenmesi, Anadolu Psikiyatri Dergisi, 15, 45-54, http://193.255.56.45:8080/xmlui/ handle/123456789/405.

Türkay, O., Ünal A., Taşar O. (2011). Motivosyenel ve Yapısal Etkenler Altında Duygusal Emeğin İşe Bağlllıpa Etkisi, ZKÜ Sosyal Bilimler Dergisi, 7(14), http://acikerisim.kirklareli.edu.tr:8080/xmlui/handle/20.500.11857/210

Ünlü, O., Yürür, S. (2011). Duygusal Emek, Duygusal Tükenme ve Görev/Bağlamsal Performans İlişkisi: Yalova'da Hizmet Sektörü Çalişanlari ile Bir Araştırma. Erciyes Üniversitesi İktisadi ve İdari Bilimler Fakültesi Dergisi, 37, 183-206, http://dergipark.ulakbim.gov.tr/erciyesiibd/article/view/5000119103.

Yıldırım, M. H., \& Erul, E. E. (2013). Duygusal Emek Davranişinin İşgörelerin Tükenmişlik Düzeylerine Etkisi. Organizasyon ve Yönetim Bilimleri Dergisi, 5(1), http://dergipark.ulakbim.gov.tr/oybd/article/view/5000145410.

Çelik M., Turunç Ö. (2011). Duygusal emek ve psikolojik sıkıntı: iş-aile çatışmasının aracılık etkisi, İstanbul Üniversitesi İşletme Fakültesi Dergisi, 40(2), 226-250, http://dergipark.gov.tr/download/article-file/98188 